\title{
Development of quail growing in Ukraine
}

\author{
Katerynych $0{ }^{1}$, Pankova S. ${ }^{2}$ \\ State Poultry Research Station of the NAAS \\ 20 Tsentralna Str., Birky village, Zmiiv region, Kharkiv oblast, 63421, Ukraine \\ e-mail: ${ }^{1}$ katerinich@ukr.net, ${ }^{2}$ svet_my@ukr.net \\ ORCID: ${ }^{1}$ 0000-0003-4865-2238, ${ }^{2} 0000-0001-7504-9878$
}

\begin{abstract}
Goal. To determine current problems of domestic quail growing concerning livestock and egg production and quail meat production. Methods. Statistical methods of analysis of the current state and determination of directions of development of the industry, methods of observation, comparative analysis, theoretical generalization. Results. Trends in the development of industrial quail growing in the domestic market of Ukraine are studied, due to the high taste qualities of eggs and meat, rapid reproducibility of production and cost recovery in the short term. The average annual number of quails in Ukraine is about 3 million heads. The annual production of quail eggs ( 0.53 billion pieces) and meat (about 1.2-1.5 thousand tons) is determined. By that indices, Ukraine is among the top ten in the world and has great prospects for further growth. Demand for quail products and low saturation of the domestic market $(25 \%)$ is also fixed, which, given the global trends in consumption of eggs and quail meat, testifies to the great prospects for the development of the industry in Ukraine. Conclusions. The quail growing industry in Ukraine has a high domestic and export potential for egg and meat production due to its special geographical, climatic and logistical position in the world.
\end{abstract}

Key words: livestock, nutrients, quail eggs, quail meat.

DOI: https://doi.org/10.31073/agrovisnyk202004-06

Poultry farming in most countries of the world occupies a leading position among other sectors of agricultural production, which is associated with the need to provide the population with animal proteins and dietary foods. Recently, a relatively young and promising branch of poultry farming, quail breeding, has been successfully developing in many countries, since quail has a number of productive and economic advantages over other bird species [1]. Rapid growth, early puberty, and a short incubation period for quail eggs make it possible to use them as an object for breeding and genetic research, receiving five or more generations per year. Therefore, much attention is paid to scientific research in this area [2].

The genetic potential productivity of Japanese quail is quite high: their egg production reaches 310 eggs per year with an average weight of $12.5 \mathrm{~g}$ [3]. Despite their small size, they are not inferior to chicken in the content of vitamins and other useful substances, and even surpass in some indicators, generally representing a unique protein-vitamin-mineral complex. Compared with a chicken egg, $1 \mathrm{~g}$ of quail contains more vitamins: A -2.5 times, B1 -2.8 and B2 -2.2 times. Five quail eggs, equal in weight to one chicken, have 5 times higher levels of phosphorus and potassium, and 4.5 times higher levels of iron [4].

Due to the high concentration of valuable nutrients, quail eggs are very useful not only as food products, but also as a valuable therapeutic agent that is widely recommended for use by physicians around the world [5]. In terms of the content of such essential amino acids as tyrosine, threonine, lysine, glycine and histidine, quail eggs are also superior to chicken [6]. Due to this, this product has antibacterial, immunomodulating, antitumor properties, normalizes the activity of the gastrointestinal tract, cardiovascular and other systems. For example, in Japan, quail eggs are well known for their ability to remove radionuclide from the body. Quail meat, which is superior in nutritional and gustatory quality to meat of all types of farm poultry, is no less valuable dietary and medicinal food product than quail eggs. Tender, juicy and flavorful quail meat is a delicacy. In addition, quail meat is used in nutrition in the treatment of diseases of the heart, stomach, liver, lungs, kidneys, chronic diseases, improves tone, and strengthens bones [7]. It contains a significant amount of potassium, which is responsible for the work of the brain, has a hypotensive effect. In addition, quail meat is a source of trace elements such as sulfur and phosphorus, necessary for normalizing metabolism, the presence of vitamin PP in it helps to improve blood microcirculation, and is also considered an excellent tool for the prevention of gout. Compared to chicken, quail meat contains several times more vitamins A, B1 and B2, as well as vitamin D, so its use can be a prevention of rickets [8].

The use of quail eggs in the diet of people can reduce the negative effects of environmental pollution by carcinogens and helps to improve the nation. With the spread of healthy eating trends and amid doctors informing them of their usefulness in the rehabilitation of people affected by radiation exposure, products obtained from quail (egg and meat) were given a proper assessment and they took a worthy place in the arsenal of nutritionists in many countries of the world, including in Ukraine [9]. In our country, due to the unhealthy environmental situation in a number of regions, the wide distribution of a medicinally valuable consumer product is also relevant and necessary no less than in Japan, Belarus and other countries [10]. Therefore, the wide possibilities of using quail as a product for dietary and medicinal purposes determine the further spread of the quail industry in the world.

The purpose of the research is to determine the capacity of the domestic market of quail production, taking into account the livestock and production indexes of eggs and quail meat, and outline the trends of development of this trend. 
Materials and methods of research. The analytical part of the work includes the collection of informational and statistical materials of official reporting, published in domestic and foreign scientific journals. The following research methods were used: theoretical generalization, economics and mathematical methods, tabular, graphic and diagram methods, methods of comparative analysis, sociological and statistical methods, observation methods, system approach.

Results. An estimated 1.4 billion quails are raised annually in the world to produce eggs and meat. Most quail (270 million heads) are kept in China, where about $20 \%$ of world production is produced [11]. The European Union produces more than 100 million quails, there is an annual increase in consumption of quail meat by $5-10 \%$, eggs by $15 \%$. But the industry is largely unregulated, and there are no official published statistics on this.

In Ukraine, this industry has developed relatively recently. The first attempts to breed quail began in the mid 60 -ies of the twentieth century. Small quail farms began to be created in the country at enterprises, as well as in personal subsidiary and private farms. Currently, poultry farms are considered large in Ukraine, which contain 100-150 thousand heads of quail, but existing quail enterprises are striving to increase the number of livestock to 300 thousand in the coming years [12]. Although domestic quail breeding is still far from European scale, today it is gaining momentum.

In Ukraine, annually they contain about 3 million heads of quail, that is, taking into account the total number of birds (about 200.0 million heads and 500-600 million broilers), their livestock does not look very convincing. Meanwhile, this poultry industry in our country developed dynamically until 2014 (Fig. 1), when over 12 years the number of quail in Ukraine increased 20 times. And although there has been a decline in this sector since 2015 due to the loss of part of the territories, today the situation has stabilized and it is time for recovery and growth.

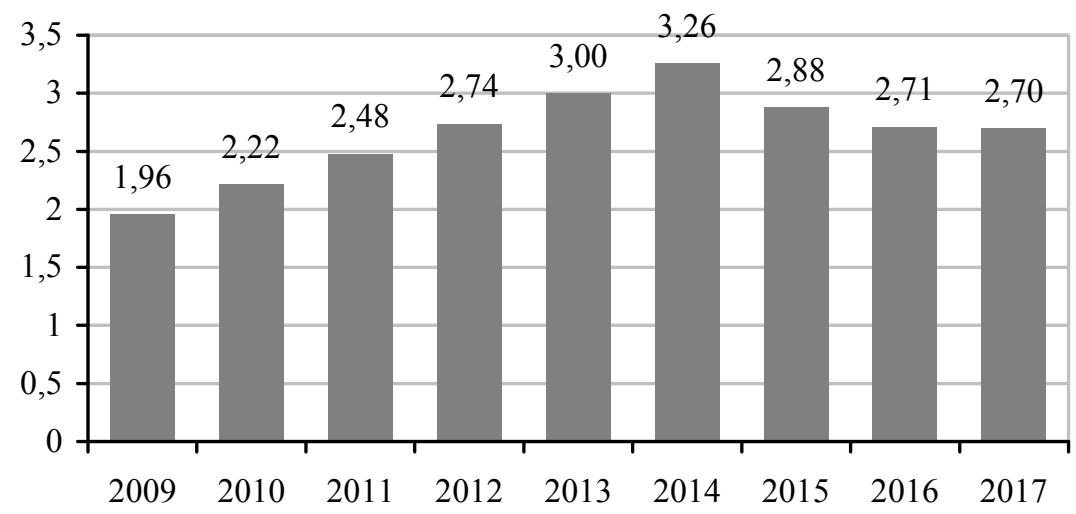

Fig. 1. Dynamics of the quail population in Ukraine (in 2015-2017, excluding the temporarily occupied territory of the Autonomous Republic of Crimea, as well as part of the zone of operations of the combined forces), million heads [13]

The world leader in the production of quail eggs is China, where about 100 billion eggs of this type of bird are produced annually. Significantly inferior to him other "players" of this market (Fig. 2).

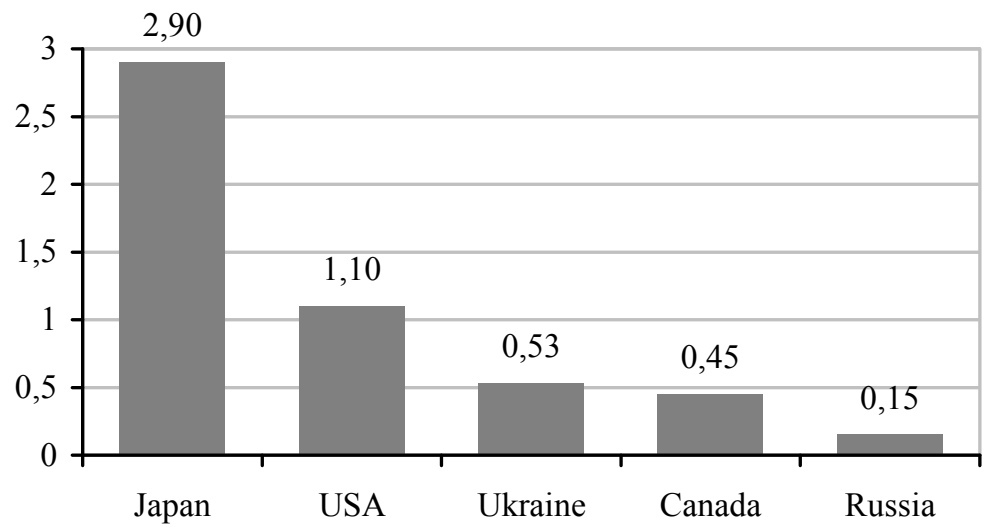

\section{Fig. 2. Production of quail eggs in different countries, billion pieces [14]}

The leader in egg consumption and the second in production (2.9 billion eggs) is Japan, with its traditions and attitude towards these products. In the USA, 1.1 billion quail eggs are produced, in Canada and Russia -2 and 7 times less, respectively. Ukraine, according to our estimates, is one of the ten producers of quail eggs in the world ( 0.53 billion pcs) and has great chances to become one of the leaders [12]. 
The efficiency and benefits of growing quail in Ukraine can be judged by production indicators. If in Ukraine about 17 billion eggs are produced annually, then quail eggs - no more than 500 million. At the same time, the number of quail in Ukraine totals about three million. Such indicators for Ukraine are quite good.

Over the past decade, there has been a gradual increase in the production of quail eggs in Ukraine (Fig. 3).

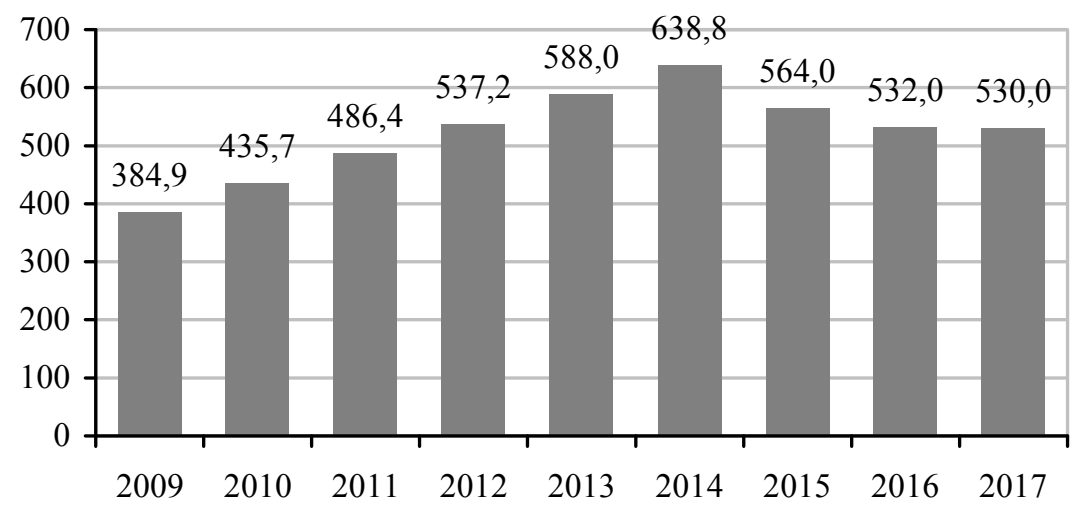

Fig. 3. Dynamics of production of quail eggs in Ukraine (in 2015-2017, excluding the temporarily occupied territory of the Autonomous Republic of Crimea, as well as part of the zone of operations of the combined forces), millions of pieces [13]

The maximum production of quail eggs in Ukraine was achieved in 2014 (638.8 million units). The separation and almost destruction of the infrastructure for the production of quail products in the temporarily occupied territories, together with the economic crisis and a decrease in living standards in the country, led to a decrease in total egg production. During 2016-2017, this figure is 530-532 million units. Despite this, Ukraine has a huge potential for the production of this type of product, and the opening of foreign markets will serve as an additional incentive for the growth of the industry.

The market for quail meat is derived from the market for quail eggs and in general lags behind it in its development. The main countries producing quail meat are China, Spain, France, Italy and the United States of America. In fig. 4 shows the volumes of production of quail meat in different countries, excluding China, which is the undisputed leader in this indicator (about 200 thousand tons annually). The next quail meat producer after China is Spain -9.3 thousand tons, which is less than $5 \%$ of the production of special types of poultry meat in the country and only $1 \%$ of the volume of broiler production.

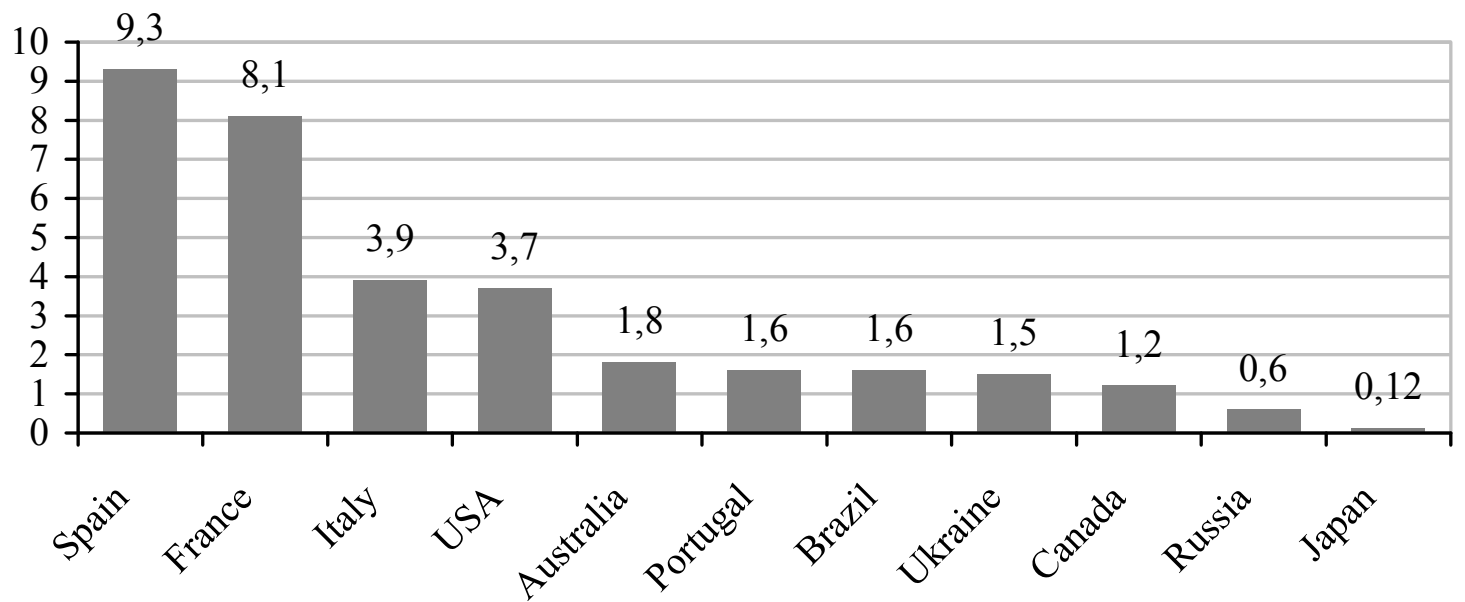

Fig. 4. Production of quail meat in different countries, thousand tons [14]

The next place is occupied by France, producing about 8.1 thousand tons of this delicious product, Italy and the USA with the production of 3.9 and 3.7 thousand tons of quail meat, respectively. Japan has a low level of quail meat production, as opposed to egg production parameters on which the country ranks second in the world.

In Ukraine, according to the Union of Poultry Farmers of Ukraine, about 1.2-1.5 thousand tons of quail meat are produced, which corresponds to the level of Brazil and Portugal (1.6 thousand tons) and is almost 2.5 times more than in Russia ( 0.6 thousand tons). Thus, quail meat breeds can also take part in replenishing the balance of meat products in the country [15]. However, quail meat is less represented in the retail network due to limited production in general, as well as due to the small number of meat species of quail. In this regard, now quail meat products are mainly concentrated in the catering system. 
At the same time, accurate and complete statistics on the production of quail products is difficult to obtain, since it is often grouped with products of other species of poultry, this information was not disclosed due to the small number of producers, most of which are simply not officially registered.

According to the Union of Poultry Breeders of Ukraine (UPBU), the domestic market of Ukraine is so far filled only by $25 \%$, so an increase in the number of quail in the future is projected at 10.8 million heads. In our opinion (SPRS NAAS), given the current trends in improving exports and the overall growth in the volume of the market for quail products in the world, an increase in the number of this species of bird is expected to reach 30 million heads. To maintain such a number of quails, only 225 thousand tons of compound feed is needed, which is $2.5 \%$ of the total poultry feed demand in Ukraine.

Therefore, taking into account all the components, which include the average level of profitability (10-15\%) for the domestic market, high technology and a small area of the premises (for keeping 10 thousand heads, about $500 \mathrm{~m}^{2}$ are needed), an adequate feeding base and high personnel potential, it is possible to predict a significant increase in the market of quail products, before the export of quail eggs and meat, as well as an increase in industrial processed products using innovative technologies. The development of scientific research in this area is also important in order to further identify new and clarify the already known biological functions of quail egg proteins and their derivatives to increase the role of these proteins in the treatment and prevention of chronic and infectious diseases.

Now the market for quail products has expanded significantly and has become accessible to the general public. At the same time, the low standard of living of most of the country's population acts as a deterrent in ensuring a balance of demand and consumption of quail products. Orientation of producers to maximize production, reduce costs and further improve product quality will significantly expand the distribution of eggs and quail meat. Considering the fact that quail eggs and meat are in increasing demand among the population, especially for dietary and medical nutrition, one can confidently and fairly reasonably focus on the positive prospects for the development of quail breeding.

At the same time, effective development of the industry is hardly possible without government support and without establishing reliable markets for products. Indeed, an intensive increase in the number of quail farms is not a solution to the problem. Only the development of government programs aimed at popularizing quail products will expand production. In 2017, the Cabinet of Ministers of Ukraine adopted a resolution according to which quail eggs and meat appeared in the order of distribution of state subsidies.

Thus, an analysis of existing trends in the development of domestic quail breeding showed that for Ukraine, which occupies a special geographical, climatic and political position, the development of the production of quail eggs and meat is very promising. In this sense, our country has a fairly high both domestic and export potential of this type of product. To popularize this industry, special attention should be paid to the distribution of specialized scientific literature on the maintenance and breeding of quail in households and on the conditions for the creation of quail mini-farms, and to inform the population about the benefits of quail eggs and quail meat.

\section{Conclusions}

The domestic market of Ukraine has a tendency towards the development of industrial quailing, which is caused by the high taste properties of eggs and meat, the rapid reproduction of products and the cost recovery in the short term. The general indicator of the saturation of the domestic market by this product is currently $25 \%$, which indicates the prospects of the industry and this direction of agribusiness.

With a population of about 3 million quails, Ukraine is among the ten largest producers in the world $(0.53$ billion pcs.) And has high chances to become one of the leaders in terms of production of quail eggs. Meat of quail is about 1.2-1.5 thousand tons, which is practically at the level of Brazil and Portugal (1.6 thousand tons) and almost 2.5 times more than in Russia (0.6 thousand tons).

The increase in the market of quail production, including the export of quail eggs and meat, is possible only with the support of the state and the introduction of state programs aimed at the promotion of quail products.

\section{References}

1. Minvielle, F. (2009). What are quail good for in a chicken-focused world? World's Poultry Science Journal, 65(4), 601-608. doi: 10.1017/S0043933909000415.

2. Minvielle, F. (2004). The future of Japanese quail for research and production. World's Poultry Science Journal, 60(4), 500-507. doi: 10.1079/WPS200433.

3. Vali, N. (2008). The Japanese quail: A review. International Journal of Poultry Science, 7(9), 925931. doi: $10.3923 /$ ijps.2008.925.931.

4. Nepomuceno, R. C., Watanabe, P. H., Freitas, E. R., Cruz, C. E. B., Peixoto, M. S. M., \& Sousa, M. L. de. (2014). Quality of quail eggs at different times of storage. Ciência Animal Brasileira, 15(4), 409-413. doi: 10.1590/1089-6891v15i424107.

5. $\quad$ Arthur, J., \& Bejaei, M. (2017). Quail Eggs. In P. Y. Hester (ed.) Egg Innovations and Strategies for Improvements (pp. 13-21). London, UK: Academic Press. doi: 10.1016/B978-0-12-800879-9.00002-0.

6. Genchev, A. (2012). Quality and composition of Japanese quail eggs (Coturnix japonica). Trakia Journal of Sciences, 10(2), 91-101.

7. Costăchescu, D. Fl., Boiteanu, P. C., \& Costăchescu E. et al. (2018). Physico-chemical and sensory characteristics of quail meat, meat line. Lucrări ştiinţifice. Seria Zootehnie, 70(23), 144-149.

8. Santhi, D., \& Kalaikannan, A. (2017). Japanese quail (Coturnix coturnix japonica) meat: Characteristics and value addition. World's Poultry Science Journal, 73(2), 337-344. doi: 
9. Owen, O. J., \& Dike, U. A. (2013). Japanese Quail (Coturnix coturnix japonica) Husbandry: A means of Increasing Animal Protein Base in Developing Countries. Journal of Environmental Issues and Agriculture in Developing Countries, 5(1), 1-4.

10. Zherebov, M. Ye. (2011). Perepilnytstvo v Ukraini [Quails in Ukraine]. Effective poultry farming, 8, 34-38. [In Ukrainian].

11. Chang, G., Chang, H., Liu, X., Xu, W., Wang, H., Zhao, W., \& Olowofeso, O. (2005). Developmental research on the origin and phylogeny of quails. World's Poultry Science Journal, 61(1), 105112. doi: 10.1079/WPS200346.

12. Kasianenko, O. I., \& Sobyna, M. M. (2012). Rehionalne roztashuvannia ta potuzhnosti vyrobnytstva perepelynykh ptakhohospodarstv $\vee$ Ukraini [Regional location and production capacity of quail poultry farms in Ukraine]. Bulletin of Sumy National Agrarian University. Series "Veterinary Medicine", 1, 71-73. [In Ukrainian].

13. Cunha, R. G. T. da. (2009). Quail meat - an undiscovered alternative. World Poultry, 25(2), $12-14$.

14. Premavalli, K., Ashok, A., Omprakash, A.V., \& Babu, M. (2015). Broiler Japanese quail rearing - a boon for both urban and rural poultry farmers. Journal of Veterinary Science \& Technology, 6(6), 96. doi: 10.4172/2157-7579.C1.013. 